低減でさたと報告した，小森(東京)は，もう少し使用で きるのではないかと尋斿たが，5回以上は硫化現象があ るため 4 回に留めたと答えた。 山本(在川)は助剤の補充 のないことから，組成のアンバランスによる硫化は当然 であると指摘した。電解法による再生は電流密度の影響 多あるので併せて検討願たい.

\section{治療-2 測定技術-1}

座長 竹谷毅 (神奈川県成人病センター)

280. 高エネルギー放射線測定（フィルム法と問題点）

東京女子医科大学病院放射線科治療部

○内山 常男・森下 耕治・菊地峻

中土井万実子. 平林 久枝

放射線測定にフィルム法は実用的である。従来のフィ ルムは，照射線量が少ない，取扱い処理が困難であった が， RP $/ \mathrm{V}_{2}$ フィルムはそれらの点が改善された。朰こで $\mathrm{RR} / \mathrm{V}_{2}$ の黑化度と線量の関係，方向依存性，使用する ファントム厚さによる変化等を従来のフィルムと比較し 測定した，黑化度のバラッキは $5 \%$ 以内である。黑化度 と線量が直線的でない，方向依存性が大 平行方向でフ フントム厚さによる差が大，等の難点があるが特性曲線 より黒化度を線量に直して補正すると電離箱, 計算機と 比較し，P.D.D., 線量分布等に士 $2 \%$ と良い結果を得た。

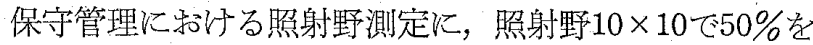
取るとXM-2フィルムは実測に近く, RP/V 2 では $5 \mathrm{~mm}$ 程長くなる。以上報告する。

281. 沉用ダイオードをセンサーに用いた線量計の応用 東海大学病院放射線科

○長山鎮治郎・高野 修一. - 桂田 忠道 津田 政行・湯之上未已

〔目的〕線量分布測定に，沉用のダイオードをセンサ 一に用いた線量計を，試作して使用したところ，精度の 良い結果が得られたので諸特性と実用上の利点，問題点 学検討した。

[結果]，線量率特性は， ${ }^{60} \mathrm{Co}, リ ニ ア ッ ク 10 \mathrm{MVX}$ 線， 電子線について直線性が得られ，再現性子良かった。

温度ドリフトについては，多くのダイオード索子につい て非常に小さく問題はないが，中に温度変化が大さく影 響するものも市るので素子の選択が必要である。杂たェ ネルギーによる感度の変化が認められた：線量計の回路 構成が簡単であること，安価に製作できる利点があり， ダイオードの特性を把握した上で使用すれば実用的で女 る.

282. コンピュータによる線量測定システム 東海大学病院放射線科
○高野 修一・長山鎮治郎・津田 政行

桂田 忠道・湯之上未已

放射線治療に於て適確な線量を与える為にも又装置の 管理上も定期的な線量分布の測定は重要な事であります。

今回我々は沉用 Mini computer を用いて自動的に線 量分布の測定を行らプログラムとシステムを開発し基礎 実験を行い実用に期するかをChamber法, Film 法等と の比較により行ないました。

結果は線量計のセンサーにダイオードを用いた為に， X-ray. Electron 共にピークのずれが有るが Profile 自 体は考慮すべさ差は認められない，依て若干の補正を加 える事により，定期的な線量分布の測定に使用出来る結 論に達しました。

283. 高エネルギー X線の BUILD-UP 領域の線量測定 について

北海道大学医学部附属病院放射線部

渡辺 良睛・五十嵐公彦・古家 輝夫

䯩エネルギーX線の. Build-up 領域線量をチェンバを 用いて測定・比較した。結果浅部の線量は照射野が大さ くなると増加し，又，SSDが小さくなっても堌加する： $3 \mathrm{~cm}$ より浅部に呿ける TPR 值はSCDにより変化し， SCD が少さくなると堌加与る，又斜めに入射した場合 に特ける浅部の線量増加子著しい. SSD 表面より約 20 $\mathrm{cm}$ の位置にシャドウトレイ・ブロッキングテーブル等 を入れると，浅部の線量は増加し照射野が大きくなると 著しくなる．治療内に空気層が在る場合，その内側の浅 い部分で線量が少なく成り，これは照射野・空気層の形 により変化します。これらの点についてさらに測定・検 討を加え，今後の課題にしたいと思います。

284. Glow Curve からみた LiF-TLD について 東海大学病院放射線科

津田 政行・高野 修一・長山鎮治郎

桂田 忠道・湯之上未已

Glow Curve を左右する因子は種々女るが，中でる Annealing が最も大きい影響を与学るし，Fading る重 要である。

Cameron $の$ standard anneal 法を基準にすると， LiF の Annealing 快 $400^{\circ} \mathrm{C} 1$ 時間後 $100^{\circ} \mathrm{C} 2$ 時間，照射後 測定までの時間は $24 \sim 48$ 時間，照射後の Annealing を 要する場合には $50^{\circ} \mathrm{C} 5$ 分が実用的で女る。

いずれにしてる，Annealing や保管状態（時間子含め て）などを一定にすること，加熱速度など装置の管理に 充分気孛配るべきで女る。

\title{
座長集約
}

